\title{
Youth participation: creating good citizens or good subjects?
}

\author{
By Helen Clark (Goldsmiths, University of London)
}

This article seeks to locate the idea of youth participation in the wider anthropological debates on nationalism and citizenship. By examining UK Government policy such as the Respect Action Plan (Home Office 2006) and the Youth Matters Green Paper (DfES 2005), the article will analyse the Government's approach to young people as citizens. Drawing on theories of republican and liberal citizenship the article will seek to show that the Government's thinking on citizenship and young people is somewhat confused, and that this has a direct impact on the forms of participation offered to young people. Using my own experience as a youth worker I will show the impact this has on youth work practice and the ways in which young people experience citizenship and participation in everyday situations. Ultimately it will be argued that the Government's approach to citizenship is leading to the creation of good subjects rather than good citizens.

\section{Introduction: young people and citizenship}

This article came into being in 2006 as a dissertation based on my experiences on two work placements while studying for an MA in Applied Anthropology, Community and Youth Work at Goldsmiths, in London. However, a recent report in The Guardian newspaper entitled 'Internet controls or citizen service' (Meikle and Branigan 2007) shows that many of the aspects and concerns around youth policy examined here are still relevant a year on. The report addresses ongoing concerns with regards to youth behaviour, specifically how to turn apparently disaffected young people into good citizens. David Cameron's wish to create a 'patriotic voluntary service' for the 'protection and nurturing of young people' (Meikle and Branigan 2007) is by no means original, but does bring us to the focus of this article, which analyses the ideas and theories of citizenship on which UK Government policy draws. In addition I will discuss how effective these policies are in engaging young people in citizenship in the UK.

The article aims to discuss whether forms of participation offered by the UK Government create good citizens or good subjects out of young people. In other words: does participation create young people who are engaged in the democratic process with the skills to question, challenge and shape the way society is run, or does it simply encourage them to do as they are told and contribute to the state? The discussion will be framed within a broader debate about the nation state and citizenship. This will show how such debates combine in and are expressed through Government policy - such as the Respect Action Plan (Home Office 2006) and the Youth Matters (DfES 2005) Green Paper on services for youth-and affect the way young people are viewed as citizens and the types of participation offered to them. 
This article is primarily based on discourse analysis, particularly when considering Government policy, as I was keen to establish what the language used said (and left unsaid) about the UK Government's approach to citizenship and young people, and in addition how this language reflected the power structures within society. The discussion will also draw on my professional practice as a youth worker in London. This will take the form of two case studies, which will illustrate certain points about youth participation. Both case studies are drawn from experience on placements carried out as part of the requirements for my MA. It is by chance and perhaps due to my own interests as a practitioner that both placements reflected aspects of youth participation. Once I had decided on this focus, I also deliberately sought out other practitioners involved in running youth participation projects. I did not carry out structured interviews, but rather conducted informal conversations with practitioners, essentially to assess how common my own experience of youth forums was, and to see if there was wider support for the conclusions I drew from this.

\section{Participation in what: a discussion of the state, citizenship and youth}

Citizenship reminds us of the relationship between the individual and the state (Beresford and Croft 1993). Definitions of citizenship are often conflated with nationality, which can be seen from the way citizenship is conferred. The two main ways of gaining legal citizenship in the UK are either inheriting it at birth from your parents or via acquiring citizenship by being born within a state territory. Both these link nationality and therefore citizenship to place, be it through inheritance of culture from parents or by being born within a particular territory (Heater 1999). Such ideas are further reinforced through the UK's complex citizenship and immigration laws. The British Nationality Act of 1981 identifies five types of citizenship, beginning with British Citizens and ending with British Protected Citizens (as cited by Heater 1999). The first of these carries the full right to abide in the UK and full civic rights, but these rights become significantly reduced as you go down the list of types of citizenship. This is the combined and muddled outcome, Heater (1999) suggests, of British colonialism and racist immigration laws aimed at preventing too many black migrants from former colonies.

This suggests that how citizenship is granted is somewhat dependent on race and culture. Terms referring to the British, such as 'island race' and 'Bulldog breed', suggest that ideas of nation and as a consequence citizenship are firmly based in ideas that are both biological and cultural (Gilroy 1992:6). This leads Gilroy (1992) to draw a distinction between formal membership of a nation, covered by law, and substantive membership, based on history, language and race. Citizenship then becomes a way not only of deciding who belongs to a nation state, but how able people feel to participate in shaping that state. Why is it important that nations are constituted by belonging? Nations, Day and Thompson (2004) argue, are territorial political entities, the political aspect of which is made real through the nation state, a governing body. Western liberal democracies are based on these boundaries (Benhabib 1996). The governments of nation states are not only able to define who belongs by controlling who comes over their borders, but also who is conferred substantive citizenship through the way it legislates and the discourse it uses about citizenship. 
In the same ways that states have the power to define who belongs and who does not in terms of race and culture, they have the power to define 'youth', by deciding when people are able to take on the full rights and responsibilities of participating in the nation state. It is worth pausing here to consider the notion of youth. That young people who are growing up go through a period of physiological change in their early life is undeniable (Mizen 2004). However, the exact dividing point between children and adults is culturally defined. For example, the idea of adolescence, a period through which children have to progress to become adults, is particular to Western nation states (ibid). It is this period, however, that is particularly important to this discussion. It is associated with the idea that young people pass through a period in which they can develop the capacity to be good citizens. In Britain, young people gain certain responsibilities as they pass through adolescence, although it has to be said that there is no discernible logic to the age at which they are accorded. At 10 years old, young people are considered criminally responsible for their actions, yet not until 16 are they judged able to make the decision to join the army and fight for their country. If at this age they do join the army, it will still not be until they are 18 that they are considered capable of becoming a full citizen and deciding on the way the country is run by voting. Age then is of political importance, it is a criterion by which young people are separated from society and then reintegrated back into it (ibid). It should be noted here that even within organisations that work with young people there is considerable variation in what age is considered young. Government policy, and as a result statutory youth services, tend to focus their work on young people aged from 13-18. The homeless charity on which the second case study in this article is based worked with young people aged 16-25. While the idea of youth may be up for debate, for the sake of progressing this discussion young people referred to in this article will be aged from 13-25.

In relation to ideas about 'belonging' and about 'youth', citizenship can be seen to be used as a method of state control and in some cases repression (Gaskell 2006). Literature on citizenship would suggest, however, that it is also more complicated than this. That citizenship is made up of different components is an idea that runs through Marshall's (1950) writing on the subject. Marshall, in looking primarily at issues of social class and equality, identifies three aspects to citizenship. The first is civil, which we have already briefly considered, and which includes rights necessary for individual freedom and equality before the law. The second is political, which again we have already touched on, and which is composed of the rights of people to participate in the exercise of political power. The final aspect of citizenship that Marshall identifies is social rights, which range from a right to a modicum of economic welfare to the right to share in a country's social heritage and to live a civilised life according to the prevailing society's standards. Here a link is drawn between citizenship and the welfare state and the services it provides, which should compensate for broader inequalities and safeguard people's rights as citizens by ensuring that they have the wherewithal to enjoy their civil and political rights (Beresford and Croft 1993). This would suggest then that governments or states can use citizenship to mitigate inequalities as well as to create them.

Marshall's (1950) discussion of citizenship focuses of the rights of citizens and what they should be able to expect from the state. On the other hand, Government rhetoric on citizenship seems to emphasise the responsibilities of citizens to the state (e.g. Home Office 2006). Before moving on to look at how UK Government policy defines and perpetuates citizenship through its policies aimed at young people, I would like 
first to look at theories of where this balance of rights and responsibilities between citizenship is thought to lie.

\section{Citizenship in theory and practice: rights, responsibility and power}

There are two main views on where the balance between citizen rights and responsibilities should lie. The idea of liberal citizenship is the most recent of these, growing out of the French Revolution and American independence (Heater 1999). Liberal citizenship is primarily concerned with the rights of the individual to property ownership, free speech and equal treatment under the law. Citizens under this model are left to pursue their own ends, held only in a loose relationship to the state through the set of civic rights described above. Similarly citizens have no real obligations to each other and are under no obligation to contribute to the public life of the state (ibid). Rather, the task of politics in liberal citizenship is to coordinate the divergent interests of private people (Benhabib 1996). This idea of citizenship has so far dominated the twentieth and twenty-first centuries.

Liberal citizenship has been both supported and challenged by capitalism. On the one hand they have certain themes in common; capitalism requires that people act in their own financial interests rather than for a common good. Capitalism also to some extent reduced the hierarchical nature of the British class system, creating a more fluid social structure (Heater 1999). However, citizenship and capitalism are also antithetical in some fundamental respects. Citizenship presents a model of the state in which all citizens are of equal status and enjoy equal rights; capitalism weakens this egalitarian political structure by giving priority to economic relationships. However, it could be said that Britain and other Western countries have conceded more than they should to capitalism and have started to view people as consumers rather than citizens (ibid). This poses a potential problem for citizenship and participation. Beresford and Croft (1993) draw a distinction between consumerism, which frames people as customers and commodifies their needs into markets to be met by the creation of goods and services, and democratic participation. They argue that democratic participation is about more than having a voice in the services provided; it is about empowerment and giving people control over their lives (Beresford and Croft 1993).

The second model of citizenship dates back much further than liberal citizenship. The republican view of citizenship (not to be conflated with current Republicanism in the US) is based in the idea of a republic, a constitutional system with some form of sharing of power to prevent an arbitrary and autocratic government (Heater 1999). This requires rather more than the loose relationship with the state favoured in liberal citizenship. In republican citizenship, people have an obligation to take part in civic life and to share in ruling and being ruled. There is in fact no room for apathy; republicanism requires that its citizens are virtuous, moral and committed to the common good (Heater 1999). The common good for Rousseau (1968), a republican theorist, is expressed in the 'general will': through contributing and submitting themselves to the general will, people are behaving as good citizens. This, for Rousseau (1968), is the way to freedom, a key aspect of republican citizenship. However, at the same time Rousseau exposes the authoritarian side of republicanism: for him those who are not obedient to the general will 'shall be forced to be free' (ibid:1.7). To summarise republican citizenship it has five main themes: the purpose of citizenship is freedom and the creation of a republican state; the style of citizenship 
emphasises community, friendship and concord; the quality of citizens, who must display virtue, patriotism and judgement; the role of the citizen, who must participate in public life and hold the government to account; and finally, how citizens can be formed or created links in with the problem of education and motivation (Heater 1999).

It is the fifth aspect of republican citizenship that is particularly relevant to this discussion of citizenship. This is the belief that good citizens are created through education; they need to be taught the importance of taking a positive interest in public affairs and the skills necessary to make them good and virtuous citizens (Heater 1999). This, together with concerns about their disaffection, brings the discussion squarely back to young people: as future citizens it is they who need to be educated in ways to create a common good. This is an idea taken up forcefully by Crick (2000), who has campaigned for citizenship to become part of the national curriculum in the UK. Crick suggests that government policy in the Thatcher era required that people were good subjects who paid their taxes, voted and knew their place, rather than good citizens striving for a common good. To move beyond this, young people must be educated in political literacy, giving them an understanding of how democracy works and how it could be improved. Such an education would not only mitigate against apathy by giving young people the tools to participate, but would also guard against exclusion and allow migrants and their children to be integrated (Crick 2000). In short, citizenship education would prepare young people to be virtuous and active citizens. Crick's idea of political literacy and indeed of citizenship education as a whole has come in for some criticism. It has been suggested that political literacy merely requires that young people have a set knowledge, skill base and attitude to participation and citizenship. True participation however requires something beyond this: it requires political education, which implies the 'development of a critical understanding of the individual's experience and position in society, social structures and processes of social change' (Back et al. 2004:192).

Thus far we have considered theoretical views of citizenship and how it is created by the state. It is time however to look at how people can act as citizens. Beyond voting for a government of their state, how can citizens exercise civic duty and be active citizens? Citizenship is essentially concerned with people's participation as members of society; participation that enables them to gain control over their lives, services provided to them by the state, their environment and political world (Beresford and Croft 1993). The type of citizenship we are discussing here would be described by Marshall (1950) as political: that is, the right to participate in the exercise of political power. Marshall is not the only writer on citizenship to pick up on the relationship between power and participation. Crick (2000) also notes that politics is mainly viewed as the relationship between the ruler and the ruled, as the differential access to and use of power over others. Participation then should allow citizens access to some of this power: that is the power to change and improve the state and its government for their own good (Beresford and Croft 1993). This however is not as straightforward as it might seem.

Arnstein (1969:216) states that 'citizen participation is a categorical term for citizen power'. She notes that there is a crucial difference between the empty ritual of participation and having real power to affect the outcome of a process. In addition the concept of participation is complicated by the fact that it is open to manipulation and can be used in various ways. Arnstein puts forward the idea of a ladder of participation, at the bottom of which are essentially forms of manipulation: types of 
participation that are designed to give people no real power but rather to educate or to cure them. The next rungs on the ladder are forms of tokenism, such as consultation and placation. Here participants may be heard and hear, but lack the power to change anything. Finally at the top of the ladder are delegation of power and citizen control, where citizens gain enough access to power to instigate change and see it through.

I have already discussed how the governments of nation states have the power to use citizenship as a tool for inclusion or exclusion. How then do citizens gain power for themselves to shape their lives and the nation state? How is power distributed and redistributed? The Home Office Citizenship Survey identifies three types of what is described as 'active community participation' (Munton and Zurawan 2003:1): civic participation, covering activities such as signing a petition, contacting a local councillor or attending a public meeting and so on; informal volunteering, or giving unpaid help to individuals or others who are not members of one's family; and finally formal volunteering, i.e. giving unpaid help through clubs, organisations or groups to benefit people or the environment. In addition and echoing some of the discussion above the survey defines active citizenship as: 'people given more opportunities and support to become actively involved in defining and tackling problems of their communities and improving quality of life' (ibid:2).

It has been shown from the discussion above that the state has the power to define who belongs and who does not. Here it also seems to be defining the types of participation offered to people and the ways in which they can participate. This is important, because as we have also seen the state is far from a neutral arbiter. It is vital to consider whether forms of participation such as volunteering really do offer people any real power to change their lot. To enable us to answer these questions it would be advantageous to look in more detail at the current UK Government's policy and thinking about citizenship, in order to gain insight into how they wish it to be constructed.

\section{Government policy and citizenship: the Respect Action Plan and Youth Matters}

The fact that the Home Office is taking the time to make a survey of citizenship suggests that the idea of citizenship and how it is viewed is very much on the Government's agenda. What, then, does the UK Government think about citizenship? What do they think the relationship between individuals and the state should be? More importantly for this discussion, what is their attitude to young people as potential citizens? To begin to answer these questions it is necessary to look at Government policy and discourse on the subject.

The Respect Action Plan (Home Office 2006) offers some interesting insights into how the current Labour Government defines inclusion and exclusion in terms of citizenship. The Respect Action Plan sets out how the Government plans to tackle what it calls 'anti-social behaviour' and to create a modern culture of 'respect'. The agenda very much emphasises the importance of stable families and cohesive communities, and that the way to create these cohesive communities is through respect. Respect, the paper argues, is something everybody understands: it relies on 'a shared understanding and clear rules and is strengthened by people acting together to tackle problems and improve communities' (ibid:5). This, however, is an issue, because a significant minority do not share this understanding of respect and as a 
consequence indulge in anti-social behaviour: 'what lies at the heart of such behaviour is a lack of respect for the values that almost everybody in this country sharesconsideration for others, a recognition that we have responsibilities as well as rights' (ibid:1). The problem of anti social behaviour, the paper suggests, begins with the family. If children do not learn appropriate values from their parents they are likely to become anti-social. It should be mentioned here that the definition of anti-social in the paper ranges from playing music too loud to 'worklessness, serious drug and alcohol misuse, even involvement in crime' (ibid:1). In addition to it being the responsibility of parents and families to instil respect in their children, such values need to be reinforced in the classroom. It is made clear however that it is not the responsibility of Government to impose good behaviour; rather, this is the responsibility of individual citizens: 'the only person who can start the cycle of respect is you' (ibid:2).

This Respect Action Plan shows a shift in Government thinking to a more republican view of citizenship. In particular, of the five main strands of republicanism highlighted earlier, the Respect Action Plan can be particularly linked to the third strand, i.e. the quality of the citizen. In one of his speeches on Britishness, Gordon Brown highlights that a sense of duty is an essential part of nationhood (Brown 2004). The Respect Action Plan clearly equates duty with being respectful to the state and to each other, and as such it requires that people act as virtuous citizens. There are also some parallels to the idea of the role of citizens: the agenda emphasises the importance of community and being active in it. In addition there is a strong emphasis on responsibilities before rights. However, it can also be seen to draw on the authoritarian side of republicanism, highlighted by Rousseau (1968): in the introduction Tony Blair writes, 'if people who need help will not take it, we will make them' (Home Office 2006:1). This has very authoritarian and threatening overtones, and can clearly be related to the earlier quotation from Rousseau: those who are not obedient to the general will 'shall be forced to be free' (Rousseau 1968:1.7). The implication of the plan seems to be that only in return for responsibility will there be opportunity for all. The language of the respect plan suggests that only people who are part of hard-working stable families adhering to a respectful way of life are entitled to services from the state and therefore considered as citizens, while others will have services forced upon them (Palmer 2006).

To return the debate to young people, it is possible to create further links between Government thinking in the Respect Action Plan and the ideas of republicanism, especially the education and motivation of citizens. The agenda highlights young people as a group of people particularly at risk of anti-social behaviour. It suggests that: 'Constructive activities promote mutual respect. They enable children and young people to contribute to their communities' (Home Office 2006:3). The second chapter of the Respect Action Plan is in fact entirely given over to how to divert young people from anti-social behaviour and how to ensure they are respectful. It is worth noting here that the Government starts from the assumption that young people are problematic, as they see them as particularly at risk of anti-social behaviour, although it gives no reason why they should be more so than any other group. The development of young people as citizens and their diversion from anti-social behaviour is addressed in more detail in the 2005 Green Paper on services for youth, Youth Matters (DfES 2005), issued by the Department for Education and Skills (DfES).

There are many aspects to Youth Matters, but for the purposes of this discussion I will focus on how it addresses the issues of young people as citizens and of participation. Essentially, Youth Matters offers young people four types of participation. The first of 
these is highlighted in the introduction, stating that the Government plans to give young people and their parents 'more say in the way local services and activities are provided and increase their choice' (DfES 2005:1). The second includes the Youth Opportunity Card and Fund. Such schemes aim to involve young people in services by giving them money to spend on the constructive activities they want. The Opportunity Card, for example, would allow the Government or parents to put money on it (depending on the economic situation of the young person), and this money would then have to be spent on a constructive activity; sports and educational activities are those particularly put forward by the Government. Opportunity Funds would be made available to local authorities to be spent at young people's discretion on services that improve their community.

The third method of participation outlined in Youth Matters states that young people will have the opportunity to be involved in the planning, delivery and inspection of all publicly-funded services in their area. The paper proposes to reinvigorate youth work by building on ideas set out previously in Transforming Youth Work (DfES 2002): particularly relevant to this discussion is the idea of youth forums. These could be used as a means to bring young people together to discuss and act on issues affecting them. Such forums could be tapped into by local authorities to discover the views of young people in order to help inform policy. The last form of participation offered to young people is linked directly to citizenship by the paper. The fourth chapter, entitled 'Young people as citizens: Making a contribution', describes the Government's plans to develop a national youth voluntary service. We have already seen that the Government links volunteering to active citizenship. Here however they also outline the benefits for young people, namely: providing and developing skills for employment, and encouraging young people to get involved in and take responsibility for their communities, thus leading to more engagement in the democratic process and local decision-making.

Youth Matters can be seen to contain many of the themes of the Respect Action Plan, which lays emphasis on the family and on schools in delivering services. Similarly it also echoes the move to a more republican way of viewing citizenship. It emphasises that young people will have to expect more responsibilities for the rights and privileges granted through the proposals in the paper: 'But with new opportunities will come a new emphasis on young people's responsibilities' (DfES 2005:1). Further, the emphasis on the need for young people to be active citizens and to contribute to the community through volunteering implies a belief in the need for citizens to be virtuous and active in public life (Heater 1999). It again shows the Government setting the agenda and proscribing what citizenship is and how it should be enacted. As discussed above, real participation and therefore citizenship requires the distribution of power to allow people to make the changes they wish for. The question remaining then, is this: does the Government view of participation and citizenship for young people offer them any real stake in power and the ability to make the changes to services provided? Furthermore, do activities such as youth forums and volunteering really teach young people about democracy and how they could change it for the better? Does it take into account Crick's (2000) criticism of the Thatcher government, which, he argues, created good subjects rather than good citizens? 


\section{Youth participation in practice}

To begin to answer some of these questions, I would like to use case studies from my professional experience to analyse two forms of participation offered to young people. The first will look at the involvement of young people in services provided to them through a youth forum in a statutory youth service, and the second will look at homeless young people and volunteering. It is hoped that these case studies will shed light on discussions of nations and citizenship as expressed through Government policy in reference to youth.

\section{Case study 1: youth forums}

This case study is drawn from my experience on a placement with a statutory youth service where I was based at an Adventure Play Ground in the borough of Lambeth, in south London. My role on the placement was to help pilot a youth forum, which would represent a section of the young people living in the borough. This involved doing group work with a youth club that had recently been set up at the Adventure Play Ground. The purpose of the group work was to help young people develop the skills needed to participate in the forum and to allow them to shape it as they wished. The creation of the youth forum was the direct result of Government policies such as those outlined in Youth Matters. Some of the expressed aims of the youth forum were to allow young people to have a say about the services delivered by the youth service, as well as to encourage young people as citizens in democratic participation. The youth forum was composed of between 8-10 young people who used the club regularly. The forums themselves took place fortnightly and were attended by young people, youth service workers and occasionally management.

During my time at the youth club, however, it became apparent that there were some problems with the youth service which were, I would argue, directly linked to Government policy on citizenship and young people. First among these was the topdown way in which the forum was initiated. The management personnel who were responsible for the youth forum were focused on getting the youth forum launched across their part of the borough. As a result many of the group work sessions were taken up with planning the launch, rather than with learning skills necessary for participation and negotiating the expectations of young people. The focus could have been said to be on the 'show' of having a youth forum and being seen to consult young people, rather than on the political education of young people by ensuring they have the skills to participate in democratic structures (Back et al. 2000).

The top-down nature of the management of the youth forum can further be seen in the forum's constitution, which was taken directly from the local Youth Council. This raised several issues. Firstly, this was done without any consultation with the young people in the forum as to how they felt about the constitution, suggesting that the youth forum would be going ahead regardless of the validity of the young people's involvement in it. Secondly, it echoes comments made earlier about the difference between political literacy and political education. The forum, for example, taught them that they should have a constitution that lays down how the forum will work and how it will be run democratically, and as such could be construed to be teaching political literacy. That is, it was trying to ensure that young people had a certain knowledge and skills base and attitudes towards participation. However, it did not move beyond this to political education, because young people were expected to accept the constitution without any discussion about what a constitution actually is, 
why it might be important, and what alternatives there might be. Therefore it could not be said to be encouraging young people to think critically about their position in society and to question existing democratic structures (Back et al. 2004). The fact that the constitution was taken directly from the Youth Council is very telling. In a discussion with a worker involved in running the Youth Council, one of its problems was highlighted as the fact that it mirrored the local council of the borough of Lambeth, which was highly bureaucratic and inaccessible to most members of the public.

Youth forums and councils then could be accused of mimicking existing decisionmaking structures without looking at their flaws. Such a way of working maintains the status quo, as it is aimed at trying to ensure that existing democratic processes and methods are valued and understood rather than encouraging young people to engage in challenging their structures and creating new ones (Back et al. 2004). I would argue that this situation is a result of the Respect Action Plan and Youth Matters, which as suggested are very authoritarian in tone, setting down specifically the kind of citizens they want and the activities they should take part in. The authoritarian attitude is reflected in the top-down management of the youth forum, and the way it is set up to mimic existing democratic structures.

Further it has been argued that Youth Matters treats young people as consumers of services rather than as citizens. The participation talked about in Youth Matters, and as a consequence the projects created and targets set at Lambeth Youth and Play Service, are around improving service delivery rather than developing young people's political education. This attitude can also be seen in the other forms of participation that Youth Matters offers young people: the Opportunity Card, for example, only allows young people to choose between existing services through the mechanism of where they spend their money. Rather than engaging in shaping society, young people in this scenario are simply choosing between products on display (Lewis et al. 2005). Such a way of viewing citizenship reduces participation to spending power: those with the most spending power will be able to choose what services are available for all. Further, this idea is based on a certain idea of rights: that young people have the right to choose between services which meet their needs. The idea of rights-based choice is much more akin to ideas of liberal citizenship, especially as they have become entwined with capitalist processes, than republican citizens participating for the good of all (Heater 1999).

The link between Government policy on participation and consumerism is highlighted by another issue that came up in discussion with people involved in running other youth forums. They indicated that youth forums are primarily set for consultation, that is, so that those in power can be seen to be consulting young people. To return to the earlier discussion on participation, consultation can be seen to be low down on Arnstein's ladder, offering people little real power and consequently not treating them as citizens (Arnstein 1969). Other workers I spoke with, also involved in youth participation schemes, felt that too often consultation is confused with participation, when in reality it is only a beginning. It is in the implementation of change and seeing it through that people learn about the responsibilities of citizenship. Such a process, however, takes time, as expectations need to be negotiated and outcomes are unpredictable.

The youth forum raised issues of citizenship and belonging in other ways. Most of the young people taking part in the youth forum were of Afro-Caribbean background. 
Many had not been born in Britain and had spent the majority of their lives elsewhere. The youth forum was not set up to cater to their concerns: its ultimate aim was to ensure that young people from each youth club in the area were elected as representatives to the Lambeth North Youth Council, as a forum for consultation on borough-wide issues. The young people, however, were not particularly interested in borough-wide issues. They had an immediate loyalty to their own youth club and to improving the facilities there, as well as maintaining an interest in and loyalty to the places they were born through family and friendship links. Their interests, then, were at once more local and more global, and they saw no contradiction in this. Because the youth forum was set up to mirror existing democratic structures, such as the council of the borough, it was unable to represent their concerns and interests as citizens and potential citizens. This would suggest that local democracy itself is not set up to represent these interests either.

\section{Case study 2: homeless young people and volunteering}

This second case study draws on experiences from my placement with a registered charity working with homeless young people in London between the ages of 16 and 25. I was placed within their training and education department, working with young people on a one-to-one basis in order to help them to access training and education. The department was in part funded by Connexions, which is a Government agency aimed at providing services for young people. The aim of the training and education department was to help young people gain skills to help them access education and ultimately employment. The young people I worked with often had little education, due to a disturbed family life, and no work experience. Moreover, due to the economic burden of living independently, they were more interested in finding work than in education or training. This was often compounded by the fact that they were claiming Job Seekers Allowance, which requires that people are seen to be active in seeking work. The general rule of thumb at my placement was that when young people's lack of experience was preventing them from obtaining work, we would recommend that they do voluntary work to gain skills. The whole set-up of the department, then, was really geared towards getting young people ready for the workforce.

The importance of volunteering in citizenship is emphasised both by the Citizenship Survey (Munton and Zurawan 2003) and in Youth Matters, which states that volunteering is a route by which young people can become involved in their communities and in democratic participation. Crick (2000), a proponent of republican citizenship, also highlights the voluntary aspect of citizenship and volunteering as enhancing the moral virtue of the citizen. However, my experience from my placement would lead me to question whether the young people I was working with were able to choose to volunteer. I would suggest, in fact, that they were coerced into volunteering through economic necessity, to help them gain employment. If participation is less than voluntary there is an essential shift in the power dynamic: when people are not choosing to participate then the process is out of their hands, and it is far from helping them gain control over their lives. This would seem to suggest that the process through which young people become volunteers is less than democratic.

Further, it raises the question of whether volunteering will give them the power necessary to participate as citizens. It is not just for young people in this position that the benefit of volunteering is questionable. The section of Youth Matters that deals 
with volunteering, as mentioned above, calls itself 'Young people as citizens: Making a contribution', but in reality it focuses on volunteering, and the types of volunteering it talks about are essentially offering a very apolitical form of participation (Smith 2005). Certainly this was true of the types of volunteering offered to young people at my placement, such as working in a charity shop to gain retail skills. This is unlikely to lead to greater engagement in the democratic process and local decision-making. While volunteering can be the first step to getting involved in the community, it is not usually in itself accompanied by any increase in control or ability to change things, although it may well increase responsibilities (Beresford and Croft 2003).

Youth Matters, however, is not just concerned with volunteering as a way to encourage young people to take on extra responsibilities as citizens. It, too, emphasises the connection between volunteering and gaining skills for work. It is however questionable whether this is compatible with democratic education: the requirements of employers do not necessarily tie in with the requirements of a good citizen. Few employers, for example, are likely to welcome employees who challenge authority structures (Jeffs 2005). The encouragement of young people into work as part of a citizenship agenda suggests that citizenship is increasingly defined as the civic duty of individuals to reduce their burden on society and build up their own social capital (Ong 1996). I would argue that such a line of thought can be seen to be running through Government policy. The above discussion of young people and volunteering can be seen to place emphasis on young people being encouraged into employment through circumstance, rather than on training or education. This is to some extent the result of Youth Matters, which encourages young people into volunteering to gain skills for work. In addition, the Respect Action Plan directly links 'worklessness' to anti-social behaviour, and as discussed seems to suggest that those who are anti-social are negating their citizenship responsibilities and are therefore not entitled to services.

As with the youth forum, then, volunteering can be seen to be more about political literacy than about political education. That is, it is about teaching a certain type of participation rather than teaching young people to question their position in society. Furthermore, due to the focus on gaining skills for employment, for homeless young people volunteering would seem to be more about contributing to the economy than to a common good.

\section{In conclusion}

To conclude this discussion I would like to return to where it began, with ideas of the nation state and youth. I would suggest that the UK Government has a confused attitude towards this age group. On the one hand, youth are seen as a group that needs protection and as a site of opportunity for creating good citizens. On the other hand, youth are seen as something threatening that needs to be controlled, which can be seen though both the Respect Action Plan and the Youth Matters Green Paper which directly links youth to anti-social behaviour. I would suggest that these contradictions have a direct impact on how young people are treated as citizens and potential citizens.

There have been two themes running through this article in relation to youth participation. They are political literacy versus political education, and the Government approach to citizenship. It has been noted that there has been a shift in 
Government thinking towards a republican mode of citizenship. It seems obvious to suggest that the focus of republican citizenship on the virtue of the citizen, on their active participation in society for the common good, to participate in ruling and being ruled, and further the emphasis on the need to educate and motivate people to enable them to be good citizens, would promote political education. That is, one would assume that education which allows young people to gain an idea of their position in society and through that to learn how to question and challenge democratic structures, together with forms of participation that enabled them to put such learning into practice, would be an integral part of republican citizenship. This however is not borne out in Government policy and practice. The discussions of the case studies have shown that the forms of participation offered to young people are much more akin to political literacy. This shines through particularly in the first case study of the youth forum, where in reality young people are being taught to value, and participate in, existing processes and institutions, rather than being encouraged to think critically about them (Back et al. 2004). Conversations with other practitioners on youth participation projects suggested that this is true of more projects than just the youth forum. Reading on the matter also suggests that political literacy rather than political education is becoming the staple of youth work, which raises the question of the ability of youth work and practitioners (including myself) to challenge such a trend (Back et al. 2000, Jeffs 2005). In my ongoing experience as a Youth Participation Worker for a statutory youth service, I often have to deal with similar issues.

The problems with youth participation that are highlighted in the case studies are due in part to confused thinking about citizenship on the part of the Government. On the one hand they seem to be promoting an idea of citizenship based on rights: the right to participate in services and the right to have a choice between services. On the other hand they seem to be drawing on a very authoritarian, responsibility-based interpretation of republican citizenship. The authoritarian tone of policy on citizenship has already been shown in discussions on the Respect Action Plan and Youth Matters, and the effect of this authoritarian tone on youth participation has been highlighted through the case studies. In the youth forum, it resulted in a top-down management style which meant that the forms of participation offered to young people did not represent their interests. This can clearly be tied to the earlier discussion of nationality: the Government can impose their idea of what nationality and consequently citizenship should be, even though that idea that bears little or no resemblance to the reality of the lives of the young people at the tail end of their policies. Furthermore, this authoritarian tone leads to a dictation of what forms of participation are relevant, and the skills necessary for them. It also leads to an emphasis on responsibilities before rights. This can most clearly be seen in Gordon Brown's speech in which he states that 'only in return for responsibility will there be opportunity for all' (Brown 2004), and is further backed up by the rhetoric of the Respect Action Plan. It can also be seen in the second case study, where the coercion of homeless young people into voluntary work is essentially a way of getting young people's labour for free, in some cases before they are able to pay taxes and benefit from them.

As a counter-weight to my critique of the Government's interpretation of republican citizenship, let me return to the idea of liberal citizenship and choice. It has been suggested that liberal citizenship has become compromised by consumerism. This has also been highlighted through the case studies. The discussion of the youth forum shows how young people are merely being offered the opportunity to choose between 
services offered to them, and are occasionally being consulted as to how they feel about these services. The second case study shows the problem of linking citizenship to the ability of the individual to reduce their burden on the nation state (and by virtue of this gain the means to participate as a consumer). In this case, economically marginalised young people are being encouraged into apolitical forms of participation that are essentially aimed at getting them into work. Building an idea of citizenship around consumerism is not likely to encourage young people into political participation. By virtue of their youth they are already likely to be economically marginalised, and even if they were able to wield more spending power, this would still not equate to democratic participation in society.

Before concluding, though, I would like to introduce a note of hope. The forum I worked with has, I believe, gone on to use and adapt the constitution they were given for their own needs. Furthermore, the Youth Opportunity Fund has, in some cases, offered some real power to young people in deciding how money can be spent on services that will benefit them. In both these cases, though, I believe this is down to individual practitioners rather than as a direct result of Government policy.

To conclude, whatever the reason behind the Government's contradictory approach to citizenship, between the ideas of liberal consumerism on the one hand and authoritarian republicanism on the other, young people are in fact being treated as subjects and not as citizens. On the one hand they are told how they must participate and on the other they are being offered limited choices. Neither approach offers young people any chance to gain skills to begin to understand and challenge their position in society or to begin to change it, and neither offers any real stake in the power of the state so that they might gain control over and change their lives.

\section{References}

Arnstein, S.R. 1969. A ladder of citizenship participation. Journal of the American Institute of Planners 4(35), 216-224.

Back, L., M. Mayo and K. Shukra. 2000. A voice for young people: an evaluation of the Lewisham Youth Participation Project. London: Goldsmiths College, University of London.

Back, L., A. Khan, M. Keith, J. Solomos and K. Shukra. 2004. Race, social cohesion and the changing politics of citizenship. London Education Review 2(3), 187195.

Benhabib, S. 1996. Democracy and Difference: Contesting the Boundaries of the Political. Princeton: Princeton University Press.

Beresford, P. and S. Croft. 1993. Citizen Involvement: A Practical Guide for Change. Hampshire: Macmillan.

Brown, G. 2004. Speech by the Rt Hon Gordon Brown MP, Chancellor of the Exchequer. Given at the British Council annual lecture, 7th July 2004. Available at http://www.politics.guardian.co.uk/print/0,24966163-107979.html

Crick, B. 2000. Essays on Citizenship. London: Continuum.

Day, G. and A. Thompson. 2004. Theorising Nationalism. Hampshire: Palgrave Macmillan. 
DfES. 2002. Transforming Youth Work. London: Department for Education and Skills (DfES).

2005. Youth Matters. London: Department for Education and Skills (DfES).

Gaskell, C. 2006. But They Just Don't Respect Us: Young Peoples' Experiences of (Dis)Respected Citizenship and the New Labour Respect Agenda. Ph.D. dissertation, Queen Mary, University of London.

Gilroy, P. 1992. There Ain't No Black In The Union Jack: The Cultural Politics of Race and Nation. London: Routledge.

Heater, D. 1999. What is Citizenship? Cambridge: Polity Press.

Home Office. 2006. The Respect Action Plan. London: UK Home Office (http://www.homeoffice.gov.uk/documents/respect-action-plan).

Jeffs, T. 2005. Citizenship, youth work and democratic renewal. In The Encyclopedia of Informal Education (http://www.infed.org/association/citizenship youth_work democratic renew al).

Lewis, J., S. Inthorn and K. Wahl-Jorgenson. 2005. Citizens or Consumers? What the Media Tell Us About Political Participation. Berkshire: Oxford University Press.

Marshall, T.H. 1950. Citizenship, Social Class and Other Essays. Cambridge: Cambridge University Press.

Meikle, James and Tania Branigan. 2007. Internet controls or citizen service: rival leaders tackle child protection. The Guardian, 7 September, available at http://education.guardian.co.uk/policy/story/0.,2164359,00.html

Mizen, P. 2004. The Changing State of Youth. Hampshire: Palgrave Macmillan.

Munton, T. and A. Zurawan. 2003. Active Communities: Headline Findings from the 2003 Home Office Citizenship Survey. London: UK Home Office. Available at http://www.togetherwecan.info/files

Ong, A. 1996. Cultural citizenship as subject making: immigrants negotiate racial and cultural boundaries in the United States. Current Anthropology 37(5), 737762.

Palmer, B. 2006. Stealing Youth: What's really behind the Government's Respect Agenda? Speech given on 7th July 2006 as part of the Festival of Resistance, London.

Rousseau, J.J. 1968 [1762]. The Social Contract, transl. and foreword by M. Cranston. Harmondsworth: Penguin.

Smith, M.K. 2005. Youth Matters: The Green Paper for Youth 2005. In The Encyclopedia of Informal Education. Available at http://www.infed.org/youthwork/green_paper.html

\section{About the author}

Helen Clark studied at Goldsmiths College, University of London where she completed an MA in Applied Anthropology, Youth and Community Work in 2006. 
She currently works as a Youth Participation Worker for Croydon Youth Service in London and can be reached at h_clark39@yahoo.co.uk 